\title{
My Backyard Jungle
}

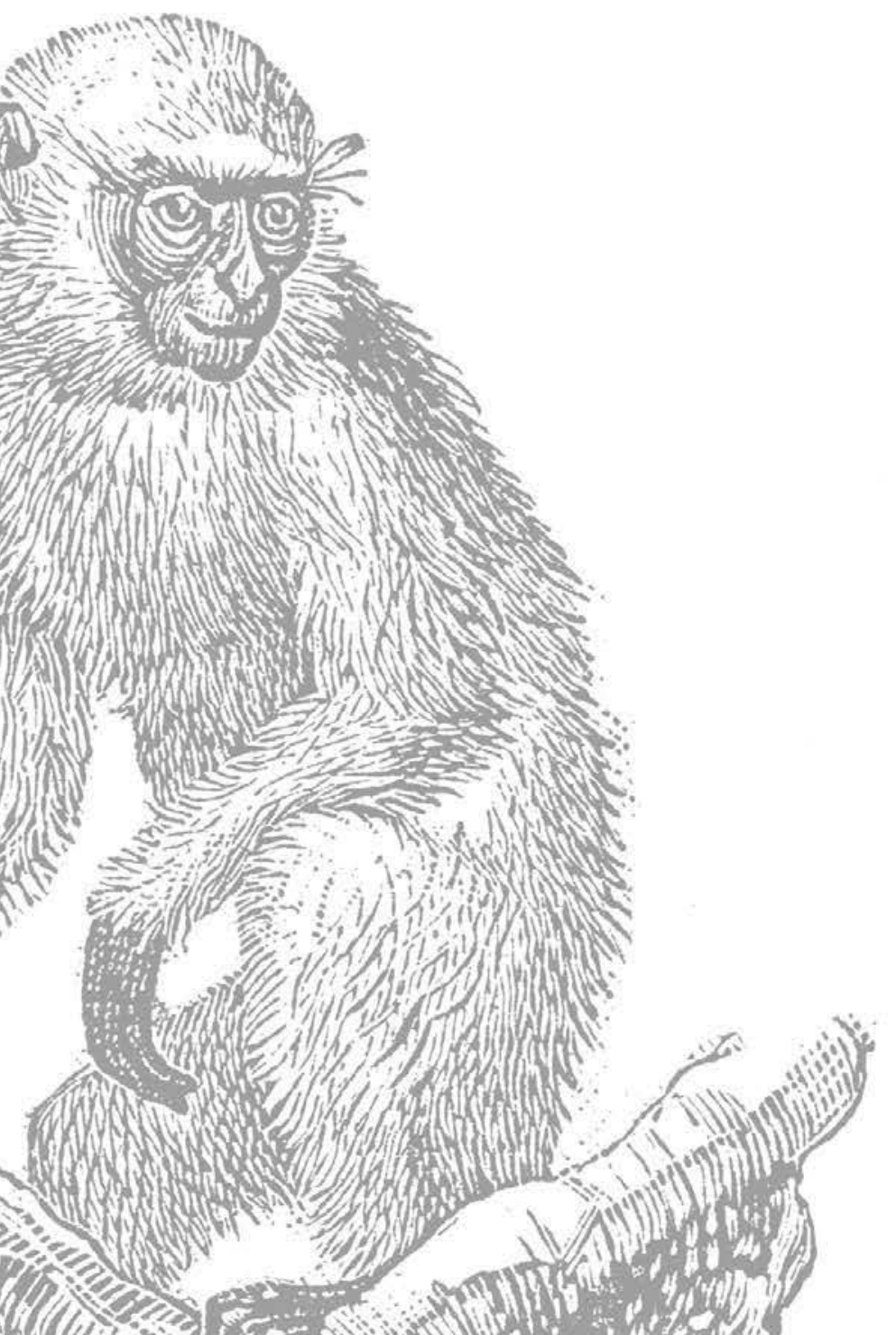



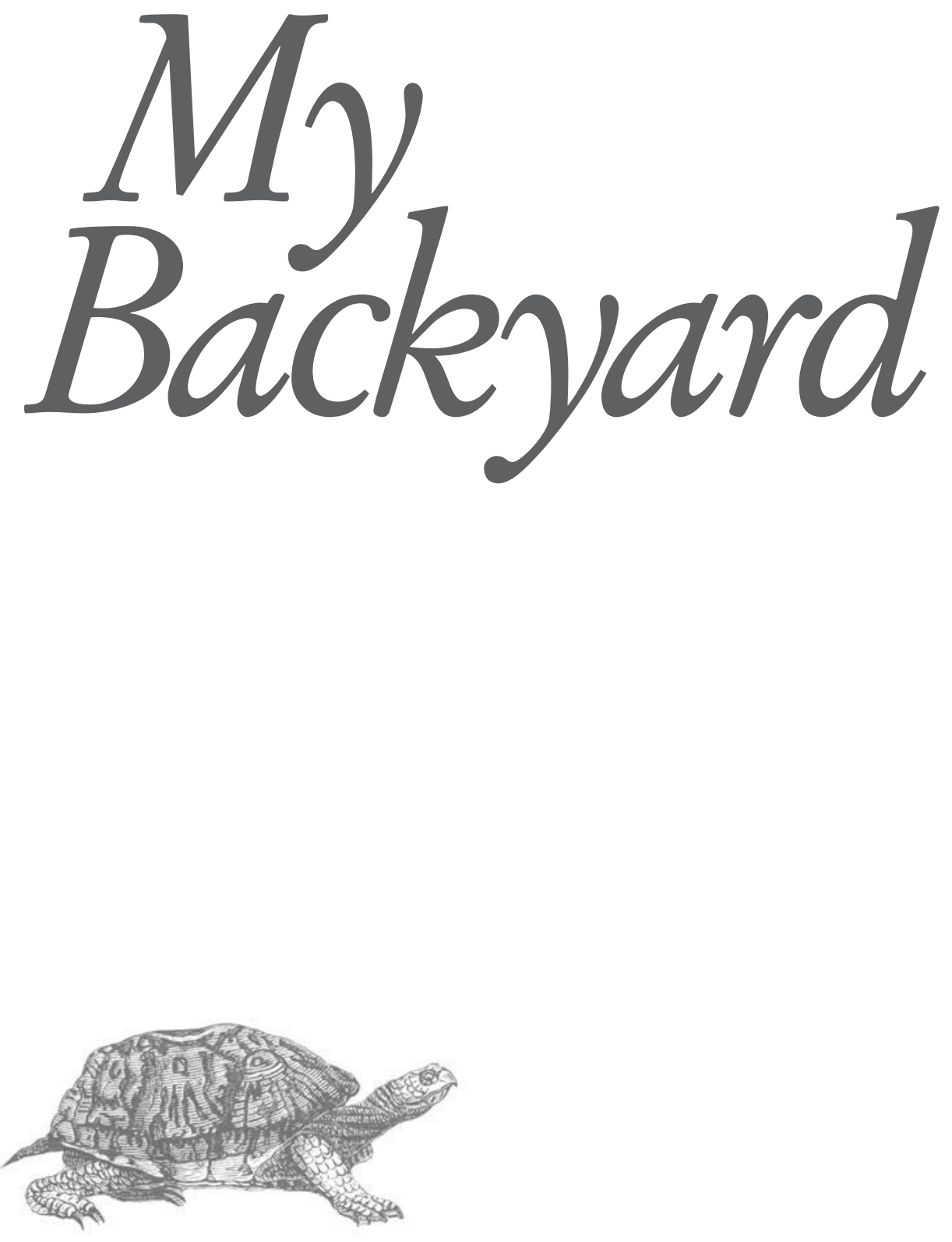


\section{James Barilla}

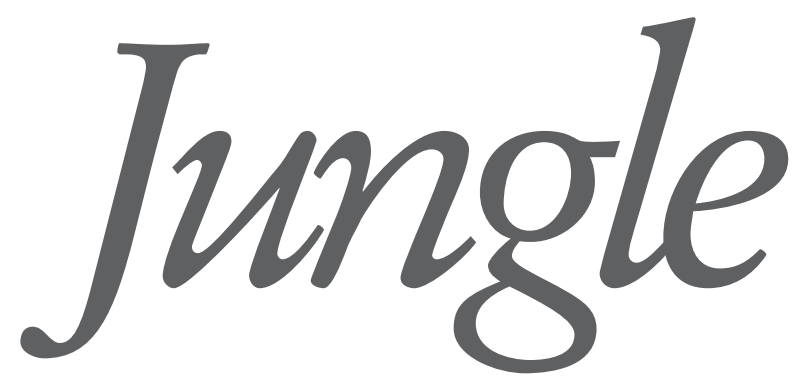

The Adventures of an

Urban Wildlife Lover

Who Turned His Yard into

Habitat and Learned to

Live with It

Yale UNIVERSITY PRESS

New Haven \& London 
Published with assistance from the foundation established in memory of Philip Hamilton McMillan of the Class of 1894, Yale College.

Copyright $@ 2013$ by James Barilla.

All rights reserved.

This book may not be reproduced, in whole or in part, including illustrations, in any form (beyond that copying permitted by Sections 107 and 108 of the

US Copyright Law and except by reviewers for the public press), without written permission from the publishers.

Yale University Press books may be purchased in quantity for educational, business, or promotional use. For information, please e-mail sales.press@yale.edu (US office) or sales@yaleup.co.uk (UK office).

Designed by James J. Johnson.

Set in type by Integrated Publishing Solutions.

Line woodcut art courtesy of The Florida Center for Instructional Technology; http://etc.usf.edu/clipart.

Printed in the United States of America.

ISBN 978-0-300-18401-3

Catalogue records for this book are available from the Library of Congress and the British Library.

This paper meets the requirements of ANSI/NISO Z39.48-1992

(Permanence of Paper).

$\begin{array}{llllllllll}10 & 9 & 8 & 7 & 6 & 5 & 4 & 3 & 2 & 1\end{array}$ 
To Nicola, Brook, and Beatrice, my fellow backyard enthusiasts 
This page intentionally left blank 